\title{
The Development of the Visual Digital-Based Practicum Manual for Microbiology to Support Students' Communication Skills
}

\author{
Risna Hani ${ }^{\mathrm{a}^{*}}$, Aminuddin Prahatam Putra ${ }^{\mathrm{b}}$, Dharmono $^{\mathrm{c}}$ \\ ${ }^{a}$ Department of Biology Education, Faculty of Teacher Training and Education, Lambung Mangkurat University, South Borneo, Indonesia \\ ${ }^{\mathrm{b}}$ Department of Biology Education, Faculty of Teacher Training and Education, Lambung Mangkurat University, South Borneo, Indonesia \\ ${ }^{c}$ Department of Biology Education, Faculty of Teacher Training and Education, Lambung Mangkurat University, South Borneo, Indonesia \\ *Corresponding author: Sutoyo S, Banjarmasin Tengah, Banjarmasin, South Borneo, 70117, Indonesia. E-mail addresses: \\ risnahani@ulm.ac.id

\begin{tabular}{|c|c|}
\hline a $\mathbf{c}$ icle info & 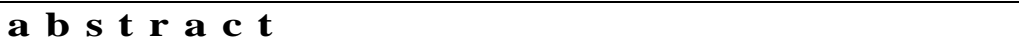 \\
\hline $\begin{array}{l}\text { Article history: } \\
\text { Received: } 26 \text { December } 2019 \\
\text { Received in revised form: } 01 \text { May } 2020 \\
\text { Accepted: } 25 \text { May } 2020 \\
\text { Available online: } 30 \text { June } 2020 \\
\text { Keywords: } \\
\text { Communication skills } \\
\text { Manual for practicum } \\
\text { Microbiology } \\
\text { Validity } \\
\text { Visual digital }\end{array}$ & $\begin{array}{l}\text { Communication skills in a microbiology practicum can be developed by composing a } \\
\text { practicum report and optimized by utilizing a practicum manual. The development of a } \\
\text { practicum manual for microbiology is necessary to facilitate students' communication } \\
\text { skills. Researchers have developed visual digital-based practicum manuals for } \\
\text { microbiology to fulfill these needs. This research aims to describe the validity of a visual } \\
\text { digital-based practicum manual for microbiology to support students communication } \\
\text { skills. This research employed the Alessi \& Trollip model. Product validity was } \\
\text { conducted through the alpha test by involving three experts and employing expert } \\
\text { validation instruments with non-test techniques to reveal the feasibility of material-based } \\
\text { media visual aspects, and software engineering aspects. The results show that the media } \\
\text { developed is completely valid on the material aspects, navigation aspects, and display } \\
\text { aspects. }\end{array}$ \\
\hline
\end{tabular}

\section{Introduction}

The $21^{\text {st }}$ century requires each individual to master various skills to succeed (Zubaidah, 2016). US-based Partnership for 21st Century Skills (P21) identifies the skills required in the $21^{\text {st }}$ century with the term "The $4 \mathrm{Cs}$ " that stands for communication, collaboration, critical thinking, and creativity. Students' ability to think critically, connect knowledge with the real world, master information technology, communicate, and collaborate is highly emphasized in $21^{\text {st }}$-century learning. (Daryanto \& Karim, 2017).

Microbiology is one of the topics in biology that studies microorganisms. Moreover, microbiology learning requires a practicum. Alhajjah (2013) asserts that the right method or approach in science learning is laboratory or practicum activities. Practicum possibly connects the conceptual sides and the methodology sides (Hindriana, 2016). Moreover, the practicum method can train the process of students' attaining skills to conduct experiments and communicate the experiment results, and these skills can be optimized by employing practicum instructions (Ismirianti, et al., 2016). 
Some indicators and criteria in microbiology research are students' communication skills and composing practicum reports. The students' ability to make reports on practicum results is the ability to communicate scientifically (Siswanto, 2014). Making reports on the results of a practicum is a form of communication skills in conveying the findings (Semiawan et al., 1992).

In the modern era when technological developments are very high, people's reading interests in printed reading materials have decreased. Indonesians' reading interest is still less than their watching interest (Saleh, 2006). This problem also possibly occurs in students who are encouraged to read practicum manuals. Rhenald Kasali as quoted by Hikmawati \& Taufik (2018) predicts that the challenge of Indonesia in the $21^{\text {st }}$ century is the increase of Indonesians' reading interests in brief materials and short sentences.

Sastria et al. (2020) explain that it is necessary to develop a practicum guide as media to help students' skills learn Biology. Furthermore, selecting the right media for practicum activities can make learning more effective and efficient (Herlenti et al., 2014). One form of media that is recently demanded is digital media. Based on the source of the material, digital media is defined as media that is stored in a certain file format and can be read or recognized by the computer used (Santoso \& Purnama, 2011). Rustaman et al. (2019) prove that the use of modules in the form of digital electronic publication (epub) beneficially guides a practicum for lectures. Learning utilizing audiovisual media is more successful than learning without utilizing media (Asmara, 2016). Ajizah and Hani (2017) deploy that there is a significant difference in learning outcomes between a class that employs a practicum manual in the form of books and a class that employs a visual digital-based practicum manual.

Technology has become an important part of the teaching and learning environment as well as humans' lives for years. The technological developments in the $21^{\text {st }}$ century and the importance of using technology in education propose that it is necessary to effectively integrate technology into the teaching and learning environment (Karakoyun \& Yapıc1, 2016). Recently, instructors have expanded their plans for learning materials and procedures by incorporating technology into learning. These new techniques include the use of computers, compact discs, video discs, and satellite communications (Heinich et al., 1999).

One of the learning media that considers the basic elements is audiovisual media. The recent development of information and communication technology, such as audio-visual media, is very relevant. Media assistance allows students to independently learn without 
limited spaces and time (Asmara, 2015). Teaching is no longer limited by classrooms because by focusing on media and computer networks, such as the internet, the world becomes a class for every student ( Heinich et al., 1999).

Communication is an important part of scientific activities, particularly in science learning (Mubarak, 2014). Communication skill is a skill to express new thoughts, ideas, knowledge, or information required in writing and speaking or verbal and nonverbal communication (NEA, 2010). Indicators of communication skills include describing the research problem/inquiry clearly in the report, communicating the report, concluding the research results, communicating the data-based results, and recommending follow-up from the research results(Depdiknas, 2003).

The purpose of this development research is to describe the validity results of developing visual digital-based practicum manuals for microbiology to support students' communication skills. Studies on the development of audiovisual-based learning media were conducted by Asmara (2015) who developed audio-visual based learning media on colloid-making and by Rahman (2016) who developed interactive learning media for the diversity of bird species. These studies developed media consisting of 2 practical topics (Asmara, 2015), 1 sub-topic of learning (Rahman, 2016), and assessments measuring learning outcomes. Furthermore, the researchers produced practicum guides consisting of 10 practicum topics as a package of practicum guides and assessments to measure students' communication skills.

\section{Method}

The type of this research was development research, and it employed the Alessi \& Trollip model that consisted of three stages: planning, designing, and developing. The subjects of this research were three experts in the Alpha test (validity testing).

\section{Data collection techniques and instruments}

Validity data in the form of quantitative data were determined by three experts, and the non-test technique of this research employed validation instruments by experts. The instruments were revised based on the validator's suggestions and consisted of very valid and feasible categories used after conducting revision and considering the validator's suggestions.

The expert validation instrument was performed by three experts to reveal the feasibility of manual practicum developed based on material aspects, visual aspects, and software engineering. The results of the expert review serve as the basis for making improvements 
(revisions) on the visual digital-based manuals for microbiology practicum before being tested.

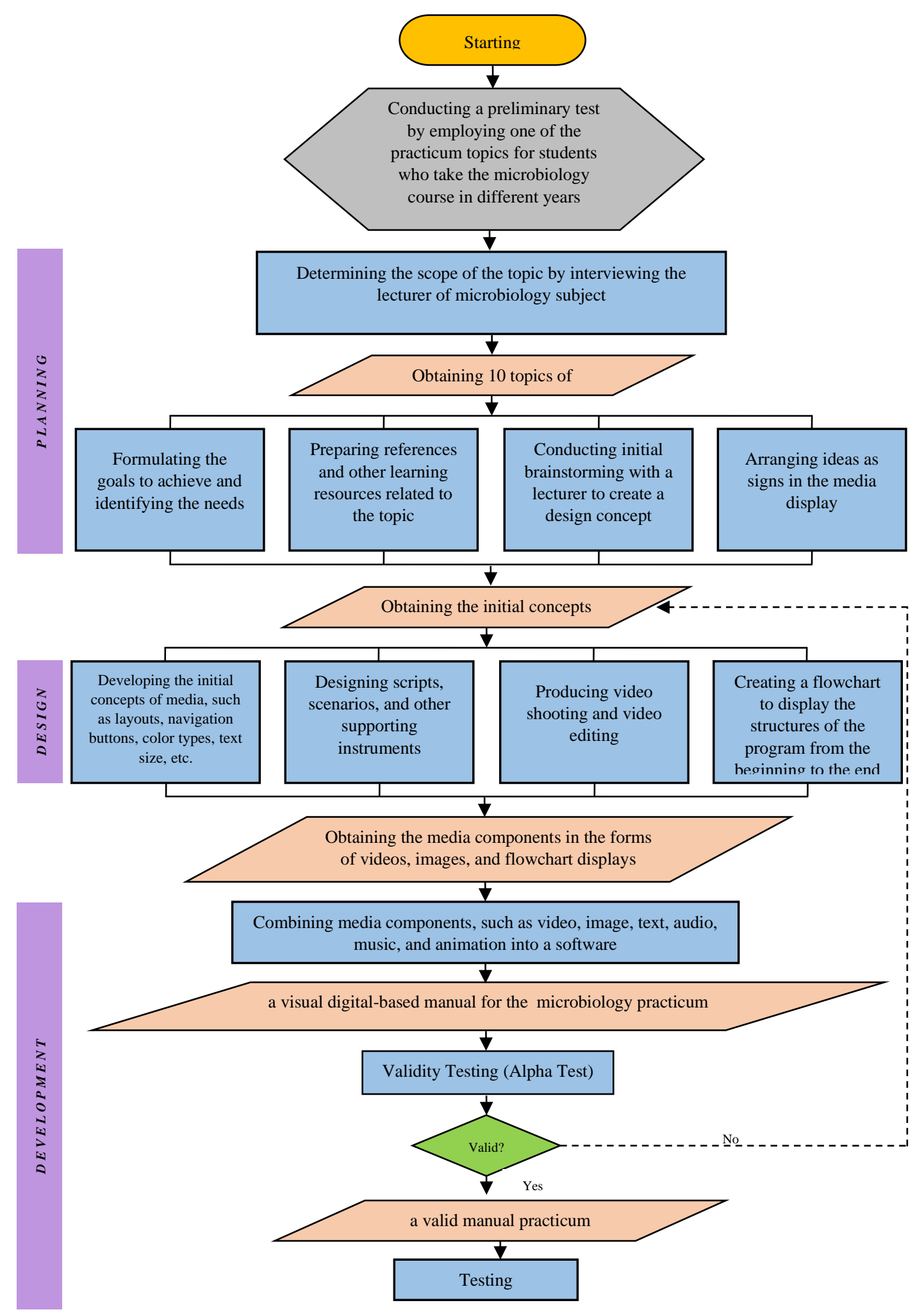

Figure 1. Research procedure flowchart 


\section{Research procedure}

The procedures of this research referred to the Alessi \& Trollip model and were based on the three stages (Alessi \& Trollip, 2001).

a. Planning. This stage consists of (1) determining the scope of the material, (2) formulating the goals to achieve and identifying the needs of developing a visual digital-based manual for practicum, (3) preparing references and other learning resources related to the material, (4) conducting initial brainstorming, and (5) arranging ideas as signs in the media display.

b. Designing. This stage consists of (1) developing the initial concept of media that includes layouts, navigation buttons, color types, text size, etc. used in the display of manual for practicum, (2) designing scripts, scenarios, and other supporting instruments, (3) producing video shooting and video editing, and (4) creating a flowchart to display the structure of the program from the beginning to the end of the digital and visual-based practical guide that will be operated by users.

c. Development. This stage consists of (1) combining media components, such as videos, images, texts, audios, music, and animation into a software up to the production of a visual digital-based manual for microbiology practicum by considering the design, and (2) conducting validity testing by three experts.

\section{Data Analysis Technique}

The data analysis techniques to determine the validity of the product were obtained from validity testing. The formula of validation values (adapted from Sugiyono, 2010):

$$
\text { Percentage validation }=\frac{\text { Score of acquisition }}{\text { Ideal Score }} \times 100 \%
$$

The formula for calculating the average total scores of each validation result from the validator (adapted from Sugiyono, 2010):

$$
\bar{X}=\frac{\sum X}{n}
$$

$\bar{X}=$ Average score $; \Sigma X=$ Total score $; \mathrm{n}=$ Number of assessors

The validation results in percentages can be matched or confirmed with validity criteria as presented in Table 1 (modified from Rahman, 2016).

Table 1 . The criterion validity for media

\begin{tabular}{cc}
\hline Criterion Validity & Level of Validity \\
\hline $90 \% \leq \overline{\mathrm{X}} \leq 100 \%$ & Very valid or usable without revision \\
$80 \% \leq \overline{\mathrm{X}}<90 \%$ & Valid or usable with minor revisions \\
$60 \% \leq \overline{\mathrm{X}}<80 \%$ & Quite valid or usable with significant revisions \\
$20 \% \leq \overline{\mathrm{X}}<60 \%$ & Less valid, not recommended for the usage, and required major revisions \\
$\overline{\mathrm{X}}<20 \%$ & Invalid, or not usable \\
\hline
\end{tabular}




\section{Result and Discussion}

The data were validated by three experts in the alpha test to determine the feasibility of the media based on material aspects, the visual aspects, and software engineering. The results of media validation are presented in Table 2. The aspects assessed consist of three parts:

\section{Material aspects}

These aspects include the suitability of practicum objectives with the material, the suitability of the presentation order, material suitability, material updating, the understandable instructions to utilize digital visual-based practicum guides, clear sequencing steps of digital visual-based practicum work, conformity with the intellectual development of students, and the contents of the elements to support indicators of communication skills in the media.

\section{Display aspects}

These aspects include overall patterns (alignments, shapes, balance, styles, color schemes, and color appeal), arrangement (proximity, directionals, figure-ground contrast, and consistency), verbal elements (lettering styles, letter sizes, and spacing), and appeals (surprise, texture, and interaction).

\section{Navigation aspects.}

These aspects include navigation consistency, navigation effectiveness, navigation functions, ease of operation, and button consistency.

Table 2. The validity test results of visual digital-based manuals for microbiology practicum

\begin{tabular}{cccccccc}
\hline \multirow{2}{*}{ Rated aspect } & $\mathbf{4}$ & $\mathbf{2}$ & $\mathbf{3}$ & Average & $\begin{array}{c}\text { Percentage of } \\
\text { media validation } \\
\text { per aspect }\end{array}$ & $\begin{array}{c}\text { Criteria per } \\
\text { aspect }\end{array}$ \\
\cline { 2 - 6 } & 62 & 64 & 65 & 63.67 & 90.95 & Very valid \\
Material & 66 & 65 & 69 & 66.67 & 88.89 & Valid \\
Display & 21 & 25 & 25 & 23.67 & 94.67 & Very valid \\
\hline Navigation & 149 & 154 & 159 & 154.00 & & \\
\hline Total score & 87.65 & 90.59 & 93.53 & 90.59 & \\
\hline $\begin{array}{c}\text { The overall percentage of } \\
\text { media validation }(\%)\end{array}$ & & & & & & \\
\hline
\end{tabular}

The results of the validity test by three experts (Table 2) reveal that the developed practicum manual is very valid in material aspects and navigation aspects and valid in the display aspects. The average results of expert validation (Table 2) were gained by employing a formula adapted from Sugiyono (2010) and matching with validity criteria modified from Rahman (2016) as presented in Table 1 . The result reveals that the product is very valid with a score is $90.59 \%$. 


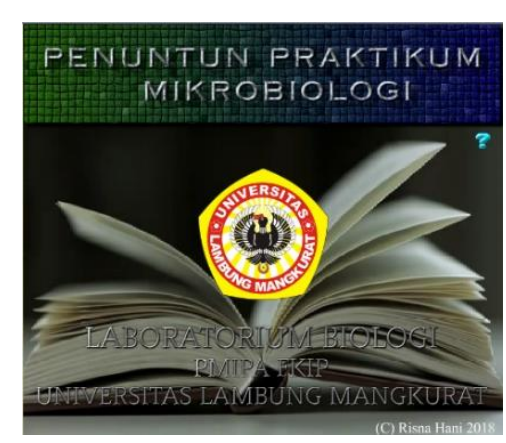

(a)

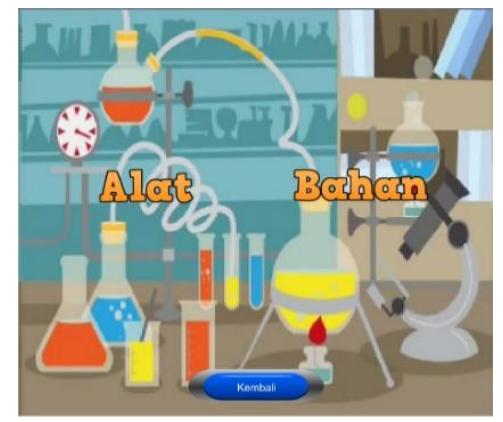

(d)

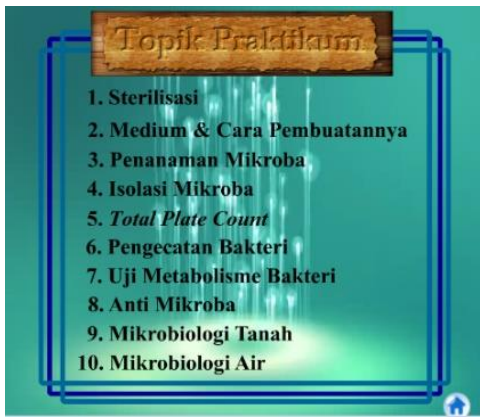

(b)

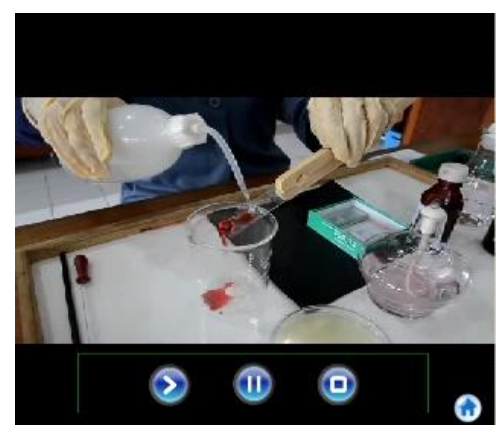

(e)

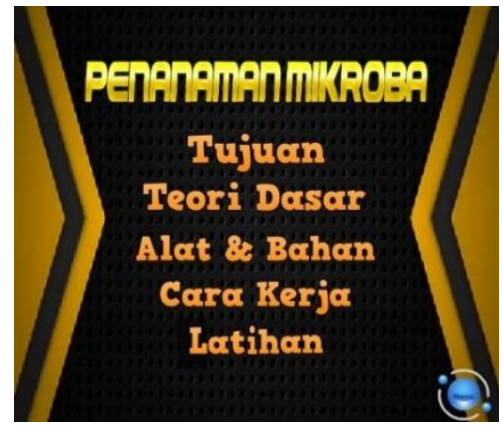

(c)

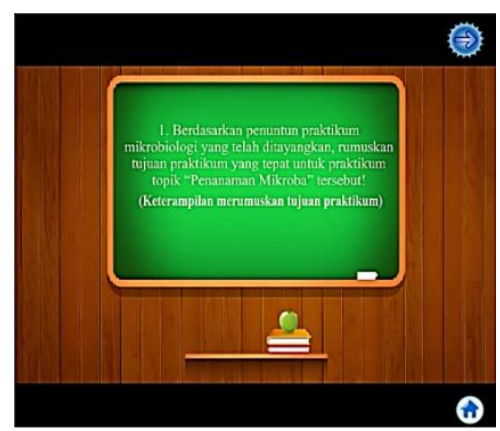

(f)

Figure 2. Examples of product displays: (a) front page; (b) main menu; (c) menu for each practicum topic; (d) sub-menu; (e) one of the tutorial videos; and (f) examples of practice questions

The results of assessment aspects reveal that the visual digital-based practicum manual in a theoretical manner can be used well in a microbiology practicum to support microbiology learning. This is because the digital visual practicum manual developed has been equipped with components that compulsorily present in the practicum manual. The components include practicum titles, practicum objectives, basic theories, tools and materials, work steps on the developed products displayed in the videos as well as images, and exercises. The exercises on this developed product are made in the form of instructions as an exercise to prepare practicum reports. The reports are adjusted to the criteria for communication skills and equipped with rubrics and examples of answers with maximum values. The components that compulsorily exist in manual for practicum (Arifin, 1995) are (1) the practicum title consisting of the identity or name given of each type of practicum and adapted to practicum material, (2) the purposes of the practicum describing aspects to test, (3) basic theory containing materials briefly, clearly, and comprehensively presented as a reference in practical activities, (4) tools and materials containing a list of tools and materials required for practical activities, (5) work steps consisting compulsory steps to conduct during practical activities, and (6) questions that aim to test the ability of the practitioner 
This validation process is conducted to determine the feasibility of a practical guide developed based on material aspects, visual aspects, and software engineering. These eligibility components must be valid before being used in the next test (Depdiknas, 2008). This consideration agrees with several studies that developed printed or digital-based practicum manuals. Some of these studies are a study by (Desnita, 2019) who developed a manual practicum for science, a study by (Fitriyani et al., 2018) who developed a flowchartbased manual for microbiology practicum, a study by (Prasetyo, 2016) who developed a science skills-based manual for microbiology practicum, studies by (Arifah, 2014), (Umah et al., 2014), (Nengsi, 2017), and (Syamsu, 2017) who developed guided inquiry-based practicum manuals, and a study by (Alexander et al., 2018) who developed an audio visualbased practicum manual for photosynthetic. Meanwhile, several studies on the development of computer or digital-based learning media were conducted by (Surahman \& Surjono, 2017) and (Ibrahim \& Ishartiwi, 2017) who developed mobile-based learning media. These studies reveal that the practicum guide and learning media developed are valid or very valid before being used in the next test. The validity includes material aspects, language aspects, display and/or graphic aspects, and navigation aspects.

The product's achievement of very valid criteria is considered by the experts' assessment on all aspects and the assessment generally of the assessment which generally obtains not far different scores. This shows the suitability of the materials contained in this media, especially the clear explanation of the practical work steps in a comprehensive sequence to make a video. Moreover, the evaluation of the navigation aspect shows that the navigation used on the video has met the criteria of consistency, effectiveness, function, and ease of operation. Meanwhile, the aspect of appearance has quite varied differences in values, such as color scheme and color appeal items. This condition probably occurs due to three validators' different points of view about the color combination used in the practicum guide media.

The experts' comments and suggestions of this visual digital-based practicum manual are very important to perfect the developed media. The revisions include rearranging the application to more fasten the open process, changing background, and font colors to make more contrasts, and improving instructions for several work steps by considering the experts' suggestions and comments. These revisions aim to perfect and comprehensively develop a practicum manual. The validation process aims to investigate the advantages or disadvantages of relevance, accuracy, language, and suitability of the product with learning (Akbar, 2013). 


\section{Conclusion}

This study produced a visual digital-based practicum manual for microbiology, and the product was validated by three experts by employing non-test techniques and instruments covering the aspects of the material, display, and navigation. The developed product is appropriate because it is valid with an average score is $90.59 \%$. The scores reveal that the quality of the three aspects is very feasible in the material, navigation, and display aspects. Thus, this product is theoretically usable in the microbiology practicum to support microbiology lectures. This research proposes several improvements for further research. Further research can investigate material aspects that include elements of media content to support students' communication skills and display aspects that include the selection of color patterns and color appeals. Furthermore, further research can pay more concerns to the color combination and the use of sound effects to produce more attractive media to gain users' positive responses.

\section{References}

Ajizah, A., \& Hani, R. (2017). Pengembangan penuntun praktikum mikrobiologi (antimikroba) berbasis media visual digital. Prosiding Seminar Nasional Pendidikan. Penguatan Pendidikan Berbasis Karakter melalui Peran Pendidik untuk Mewujudkan Generasi Emas Indonesia. Moment of General Physics Education. Pendidikan Fisika Universitas Lambung Mangkurat, pp. 191:200.

Akbar, S. (2013). Instrumen perangkat pembelajaran. Remaja Rosdakarya.

Alessi, S. M., \& Trollip, S. R. (2001). Multimedia for learning: methods and development. 3rd ed. Allyn and Bacon-A Pearson Education.

Alexander, A., Rahayu, H. M., \& Kurniawan, A. D. (2018). Pengembangan Penuntun Praktikum Fotosintesis Berbasis Audio Visual Menggunakan Program Camtasia Studio di SMAN 1 Hulu Gurung. Jurnal Pendidikan Sains Indonesia, 6(2), 75-82. http://www.jurnal.unsyiah.ac.id/ JPSI/article/view/12075

Alhajjah, P. S. (2013). Perbandingan penggunaan LKS teks, gambar, dan video terhadap keterampilan proses sains dan pengetahuan prosedural (Doctoral dissertation, Universitas Pendidikan Indonesia). http:// repository.upi.edu/2006/

Arifah, I. (2014). Pengembangan buku petunjuk praktikum berbasis guided inquiry untuk mengoptimalkan hands on mahasiswa semester II program studi pendidikan fisika universitas muhammadiyah purworejo tahun akademik 2013/2014. RADIASI: Jurnal Berkala Pendidikan Fisika, 5(1), 24-28.

Arifin, M. (1995). Pengembangan program pengajaran bidang studi kimia. UNAIR Press.

Asmara, A. P. (2015). Pengembangan media pembelajaran berbasis audio visual tentang pembuatan koloid. Jurnal Ilmiah Didaktika, 15(2), 156-178. https://jurnal.arraniry.ac.id/ index.php/didaktika/article/view/ 578

Daryanto \& Karim, S. (2017). Pembelajaran abad 21. Gava Media. 
Desnita, R. S. (2019). Development of ipa guiding practicum with constructivism oriented for junior high school student at class vii. International Journals of Sciences and High Technologies, 13(1), 31-38. http://ijpsat. ijsht-journals.org

Fitriyani, D., Putra, A. P., \& Amintarti, S. (2018). The validity of flowchart-based microbiology practicum handbook for the biology students of fkip ulm. European Journal of Education Studies, 5(1), 14-25. https://doi.org/10.5281/zenodo.1400787

Heinich, R., Molenda M., Russel, J. D., \& Smaldino, S. E. (1999). Instructional media and technologies for learning, 6th edition. Prentice Hall, Inc.

Herlenti, H., Syamsurizal, S., \& Asyhar, R. (2014). Pengembangan media praktikum laboratorium virtual untuk pembelajaran optika kelas VIII SMP Negeri 1 Tungkal Ulu. Edu-Sains: Jurnal Pendidikan Matematika dan Ilmu Pengetahuan Alam, 3(2), 57-63. https://doi.org/10.22437/jmpmipa.v3i2.1896

Hikmawati, V. Y., \& Taufik, L. M. (2017). Urgensi strategi membaca pada pembelajaran biologi masa depan. Jurnal Bio Educatio, 2(2), 40-48. http://www.jurnal. unma.ac.id/index.php/BE/article/view/758.

Hindriana, A. F. (2016). The development of biology practicum learning based on vee diagram for reducing student cognitive load. Journal of Education, Teaching and Learning, 1(2), 61-65.

Ibrahim, N., \& Ishartiwi, I. (2017). Pengembangan media pembelajaran mobile learning berbasis android mata pelajaran IPA untuk siswa SMP. Refleksi Edukatika, 8(1), 80-88. https://doi.org/10.24176/re.v8i1.1792

Ismirianti, U. D., Dewi, N. R., \& Parmin, P. (2016). Pengaruh petunjuk praktikum guided discovery terhadap keterampilan melakukan percobaan dan mengkomunikasikan hasil pada tema tekanan. Unnes Science Education Journal, 5(2), 1261-1271. https://journal.unnes.ac.id/sju/index. php/usej/ article/view/13145

Karakoyun, F., \& Yapici, İ.Ü. (2016). Use of digital storytelling in biology teaching. Universal Journal of Educational Research, 4(4), 895-903. http://www.hrpub.org/journals/article_info.php?aid=3628

Mubarak, F. A. (2014, September). Kajian teoritis model productive: Suatu model pembelajaran fisika berbasis proyek yang dikembangkan melalui kegiatan komunikatif. In Seminar Nasional Pendidikan Sains IV 2014. Sebelas Maret University.

NEA. (2010). Preparing $21^{\text {st }}$ Century Students for a Global Society, An Educator's Guide to the "Four Cs". http://www.nea.org/assets/docs/A-Guide-to-Four-Cs.pdf

Nengsi, S. (2016). Pengembangan penuntun praktikum biologi umum berbasis inkuiri terbimbing mahasiswa biologi STKIP payakumbuh. Jurnal Ipteks Terapan, 10(1), 47-55. https://doi.org/10.22216/jit.2016.v10i1.343.

Prasetyo, M. M. (2016). Pengembangan penuntun praktikum mikrobiologi berbasis keterampilan proses sains mahasiswa pendidikan biologi uin alauddin makassar. Jurnal Biotek, 4(1), 1-20. https://journal.uinalauddin.ac.id/index.php/biotek/article/view/ 1766

Rahman, F. R. (2016). Pengembangan media pembelajaran interaktif keanekaragaman jenis burung di panjaratan pada konsep keanekaragaman hayati SMA/MA [Tesis]. Program Studi Magister Pendidikan Biologi, Program Pascasarjana FKIP ULM, Banjarmasin.

Rustaman, A. H., Iqbal, M., \& Amelia, W. (2019). Pengembangan modul digital praktikum komputer grafis 1 dalam format elektonik publication (epub) untuk meningkatkan pemahaman teknik grafis mahasiswa desain komunikasi visual (topik: digital imaging). 
JISIP (Jurnal Ilmu Sosial dan Pendidikan), 3(1), 224-228. http://dx.doi.org/10.36312/jisip.v3i1.647

Saleh, A. R. (2006). Peranan teknologi informasi dalam meningkatkan kegemaran membaca dan menulis masyarakat. Jurnal Pustakawan Indonesia, 6(1), 46-49.

Santoso, B., \& Purnama, B. E. (2011). Perancangan studio mini berbasis multimedia universitas surakarta. Speed-Sentra Penelitian Engineering dan Edukasi, 2(2), 17-25. http://dx.doi.org/10.3112/speed.v2i2.823

Sastria, E., Novinovrita, M., \& Haryanto, T. (2020). Pengembangan penuntun praktikum biologi umum berbasis problem solving dengan menggunakan $3 \mathrm{~d}$ pageflip untuk menumbuhkan keterampilan kerja ilmiah mahasiswa biologi. Tarbawi: Jurnal Ilmu Pendidikan, 16(01), 101-109. http://ejournal.iainkerinci.ac.id/index.php/tarbawi/article/ view/574/346

Semiawan, C. R., Tangyong, A. F., Belen, S., Matahelemual, Y., \& Suseloardjo, W. (1992). Pendekatan Keterampilan Proses: Bagaimana Mengaktifkan Siswa dalam Belajar. Jakarta: Grasindo.

Siswanto, J. (2014). Kemampuan mahasiswa dalam mengkomunikasikan hasil praktikum fisika dasar. Prosiding Seminar Nasional Hasil-Hasil Penelitian (SNHP-IV). Lembaga Penelitian dan Pengabdian Kepada Masyarakat Universitas PGRI Semarang, 319:323. http://prosiding.upgris.ac.id/index.php/LPPM_2014/LPPM/paper/view/928

Sugiyono. (2010). Metode penelitian pendidikan (pendekatan kuantitatif, kualitatif dan $R \& D$ ). Alfabeta.

Surahman, E., \& Surjono, H. D. (2017). Pengembangan adaptive mobile learning pada mata pelajaran biologi SMA sebagai upaya mendukung proses blended learning. Jurnal Inovasi Teknologi Pendidikan, 4(1), 26-37. https://journal.uny.ac.id/index.php/jitp/article/view/ 9723/9311

Syamsu, F. D. (2017). Pengembangan penuntun praktikum IPA berbasis inkuiri terbimbing untuk Siswa SMP siswa kelas VII semester genap. Bionatural: Jurnal Ilmiah Pendidikan Biologi, 4(2), 13-27. https://ejournal.stkipbbm.ac.id/index.php/bio/article/view/190

Umah, S. K., Sudarmin, S., \& Dewi, N. R. (2014). Pengembangan petunjuk praktikum ipa terpadu berbasis inkuiri terbimbing pada tema makanan dan kesehatan. Unnes Science Education Journal, 3(2), 511-518. https://doi.org/10.15294/usej.v3i2.3348

Zubaidah, S. (2016, December). Keterampilan abad ke-21: Keterampilan yang diajarkan melalui pembelajaran. In Seminar Nasional Pendidikan dengan Tema "isu-isu strategis pembelajaran MIPA Abad 21 (Vol. 21, No. 10). 